\title{
Turnustjenestens utfordringer
}

\author{
Turnustjenesten står overfor store utfordringer fordi det er for få turnusplasser og fordi det faglige innholdet \\ varierer. Tiden er nå moden for å se på om opplæringsbehovet etter endt studium kan ivaretas bedre ved \\ å starte direkte på spesialistutdanning heller enn å gå via turnustjenesten.
}

Myndighetene har i mer enn ti år visst at det er store utfordringer med turnustjenesten - både når det gjelder kvalitet i form av læringsutbytte og fordi antallet påmeldte vil overstige antall tilgjengelige plasser. I 1997 nedsatte Helsedirektoratet en arbeidsgruppe som skulle se på turnusordningen (1). Rapporten konkluderte med at det var grunn til bekymring. Siden den gang er behovet for antall plasser økt, i og med at tilgangen til norsk turnustjeneste er fri for alle nyutdannede cand.med.-er, uavhengig av statsborgerskap og studieland. Det er nå 1013 påmeldte til turnusstart $i$ august $i$ år, 447 av disse har studert ved norske universiteter. Ved siste turnustrekning var det 396 plasser til fordeling. Det er varslet at ventetiden for turnusstart kan bli ett år allerede ved oppstart i februar neste år. Når unge mennesker i etableringsfasen får livet satt på vent, er det problematisk for dem det gjelder, men det har også en samfunnsøkonomisk side. Det er derfor viktig å se kritisk på dagens turnusordning for å vurdere om en annen organisering vil gi tilsvarende læring og samfunnsmessig nytte.

\section{Skikkethet}

Formålet med turnustjenesten da den ble opprettet i 1954 var å gi praktisk opplæring og kjennskap til det norske helsesystemets målsetting og oppbygning (2). Etter fullført turnus skal legen ha nok kunnskap til å jobbe i allmennpraksis, mens sykehuslegen har fått innblikk i hvordan det er å sitte «ute» med et usortert pasientmateriale. Dette øker forståelsen mellom ulike ledd i helsevesenet. Sykehusturnus er også tenkt som en sikkerhet for at leger som skal jobbe i allmennpraksis, er faglig og personlighetsmessig skikket. Denne funksjonen er truet av at det mange steder er tredelt turnustjeneste og legene bare er fire måneder på hver sykehusavdeling. Det betyr mindre kontinuitet og mindre kontakt mellom veileder, avdelingsledelse og turnuslege og stiller strenge krav til veiledningen for å sikre en adekvat vurdering av skikkethet.

Bjerkeset og medarbeidere (3) viser i dette nummer av Tidsskriftet at oppnåelse av målbeskrivelse og veiledning i turnus varierer. Ved somatiske avdelinger er det under $20 \%$ som får regelmessig veiledning, i psykiatri under $50 \%$. Det vil si at turnustjenestens funksjon som siste skanse for à vurdere skikkethet er fiktiv. Bare 36\% av turnuslegene oppnådde målbeskrivelsen i kirurgi, på medisinsk avdeling var tallet $46 \%$. Utover behandling av enkle sår og brudd/luksasjoner var det under en tredel som fikk utføre øvrige prosedyrer. Dette kan dels gjenspeile at mengden prosedyrer ved avdelingen er for lav til å ha turnusleger, men når bare $65 \%$ av turnuslegene på medisinsk avdeling oppgir at de har utført «injeksjon av medikament», sier det mer om holdningen til å oppnå målbeskrivelsen enn om muligheten til å få gjennomført den.

Turnustjenesten har vært en del av bemanningsplanen for sykehusene, og turnuslegene har utgjort en viktig arbeidskraft i kommunene. Helsedirektoratet har foreslått å erstatte turnustjenesten med «nybegynnerstillinger» med en varighet på to år (4). Det er videre foreslått at legene ansettes etter søknad og ikke fordeles etter loddtrekning, slik det er i dag. Torunn Janbu utrykker i Tidsskriftet nr. 18/2010 (5) bekymring for at distriktene vil få problemer med legedekningen dersom de ikke blir tildelt turnuslege. Jeg tror ikke det vil bli noe stort problem.

For det første er alle nyutdannede nødt til å kvalifisere seg gjennom en nybegynnerstilling, og det er ikke mange nok av disse i sentrale strøk. For det andre kan kommunen bruke spesielle virkemidler for å få dekket stillingene, for eksempel lønnet ferie eller god standard på boligen. Dette er en vinn-vinn-situasjon - turnuslegen får et bedre tilbud, kommunen kan rekruttere en turnuslege som ønsker å ha turnus i på stedet, og sjansen for at denne legen blir er sannsynligvis mye større enn dersom hun var blitt plassert i kommunen etter loddtrekning. At noen nyutdannede leger vil velge å vente på en turnusplass i sentrale strøk, vil være uunngåelig, men dette vil neppe utgjøre en stor del av turnuslegegruppen.

\section{Konkurranse om jobbene}

En mer reell bekymring er hvordan ansettelsen vil foregå. Studenter i Norge har ikke karakterer, og bekjentskap og trynefaktoren vil spille en rolle. Da blir det viktig med arbeidserfaring i løpet av studietiden, sommerjobb og eventuelt forskning. I tillegg vil sykehusene måtte innkalle til intervju for å få et best mulig inntrykk av søkeren. Dette er konkurranse som fremtidige leger må akseptere. Det som vi imidlertid må unngå, er at nyutdannede leger jobber gratis for å sikre seg turnustjeneste. Hospiteringsordninger etter endt studium der legen ikke får lønn, må overvåkes og ikke aksepteres i de tilfellene legen blir brukt som gratis arbeidskraft. Dette stiller krav til både arbeidsgiver og til Legeforeningen som fagforening.

Turnustjenestens berettigelse må være at den gir noe mer enn det å begynne spesialiseringen direkte etter endt grunnutdanning. Hensynet til breddekompetanse, kjennskap til helsevesenets oppbygning og samfunnsmessige hensyn som legefordeling til distriktene kan være slike grunner. Søknadsbasert turnustjeneste er et skritt i riktig retning for å løse plassmangelen. Kvaliteten på innholdet er imidlertid fremdeles varierende, ti år etter at Helsedirektoratet la frem sin rapport.

Min påstand er at det faglige innholdet kan ivaretas av spesialistutdanningen. Behovet for breddekompetanse vil variere fra spesialitet til spesialitet. Mens seks års grunnutdanning med praksis underveis kan være tilstrekkelig for forsvarlig basis i enkelte spesialiteter, vil andre ha behov for ytterligere sideutdanning. Dette er erkjent i dagens spesialistutdanning i det at f.eks. gynekologer trenger ett år generell kirurgi og at man for å bli spesialist i allmennmedisin må jobbe ett år på sykehus. Tiden er moden for at turnustjenestens berettigelse vurderes kritisk med tanke på om andre løsninger, f.eks. en utvidet spesialistutdanning, bedre ivaretar enkeltpersoners og samfunnets behov.

\section{Ragnhild Øydna Støen \\ r.o.stoen@medisin.uio.no \\ Ortopedisk avdeling \\ Oslo universitetssykehus, Ullevål \\ 0407 Oslo}

\section{Oppgitte interessekonflikter: Ingen}

Litteratur

1. Turnustjenesten for leger. Turnusrapport I-1004B Oslo: Sosial- og helsedepartementet, 2001.

2. Forskrift om praktisk tjeneste (turnustjeneste) for å få autorisasjon som lege. www.lovdata.no/ cgi-wift/ldles?doc=/sf/sf/sf-20011220-1549.html (23.2.2011)

3. Bjerkeset O, Romild U, Haugdahl HS. Evaluering av turnustjenesten i sykehus, Tidsskr Nor Legeforen 2011; 131: 824-7.

4. Nybegynnerstillinger for leger. www.helsedirektoratet.no/personell praktisk tjeneste turnus/nybegynnerstillinger for_leger_743174 (23.2.2011).

5. Janbu T. Turnustjeneste. Tidsskr Nor Legeforen 2010; 130: 1855. 